This item was submitted to Loughborough's Research Repository by the author.

Items in Figshare are protected by copyright, with all rights reserved, unless otherwise indicated.

\title{
An experimental investigation of the heat transfer and energy storage characteristics of a compact latent heat thermal energy storage system for domestic hot water applications
}

\section{PLEASE CITE THE PUBLISHED VERSION}

\section{PUBLISHER}

Elsevier BV

\section{VERSION}

AM (Accepted Manuscript)

\section{PUBLISHER STATEMENT}

This paper was accepted for publication in the journal Energy and the definitive published version is available at https://doi.org/10.1016/j.energy.2019.116083.

\section{LICENCE}

CC BY-NC-ND 4.0

\section{REPOSITORY RECORD}

Fadl, Mohamed, and Philip Eames. 2019. "An Experimental Investigation of the Heat Transfer and Energy Storage Characteristics of a Compact Latent Heat Thermal Energy Storage System for Domestic Hot Water Applications". figshare. https://hdl.handle.net/2134/9784235.v1. 


\title{
An experimental investigation of the heat transfer and energy storage characteristics of a compact latent heat thermal energy storage system for domestic hot water applications
}

\author{
Mohamed Fadl, Philip C. Eames \\ m.s.fadl@lboro.ac.uk; p.c.eames@lboro.ac.uk
}

Centre for Renewable Energy Systems Technologies (CREST), Wolfson School of Mechanical, Electrical and Manufacturing Engineering, Loughborough University, Leicestershire LE11 3TU, UK

\begin{abstract}
This paper presents the experimental performance analysis of a latent heat thermal energy storage system (LHTESS) designed for domestic hot water (DHW) applications. The designed, fabricated and characterised thermal store comprised of a vertically oriented multi-pass tube heat exchanger in a rectangular cross-section container filled with phase change material (PCM) paraffin wax RT44HC. The experimental investigation evaluated the heat transfer within the system, measured the transient temperature distribution, determined the cumulative thermal energy stored, charging and discharging time and the instantaneous charging and discharging power. The experimental work was conducted under controlled experimental conditions using different heat transfer fluid (HTF) inlet temperatures and different volume flow rates for store charging and discharging. It was found that during charging natural convection in the melt played a significant role. During discharging thermal conduction dominates and natural convection has an insignificant impact on the LHTESS performance. This is due to the development of a solid layer of PCM around the heat transfer tubes which increases the thermal resistance and reduces heat transfer to the liquid PCM. Higher HTF inlet temperature during charging significantly decreased store charging time. Increasing HTF inlet temperature from 60 to $70{ }^{\circ} \mathrm{C}$ shortened the charging time by 3.5 hours, a further increase to $80{ }^{\circ} \mathrm{C}$ decreased melting time by a further 2 hours.
\end{abstract}

This study illustrates the extent to which LHTESS, and heat exchanger designs need to be improved to meet the desired charge/discharge time requirements for most short-term storage applications and that a broad range of domestic and commercial heat demands can be fulfilled by assembling several LHTESS units to operate in parallel. 
Keywords: Latent heat, PCM, Thermal energy storage, Natural convection, Multi-pass tube heat exchanger, Experimental investigation.

\section{Introduction}

Reducing energy consumption in buildings and/or substitution with low/zero-carbon alternatives is one of the critical components in meeting carbon reduction commitments. In the United Kingdom, it has been estimated that the housing sector alone is responsible for a quarter of the total carbon emissions of the country [1]. The UK government established a policy of zero-carbon homes [2] to ensure that all new dwellings generate as much energy on-site-through renewable sources, such as wind or solar power as they would use for heating, hot water, lighting and ventilation. The policy is part of the UK Government's wider strategy to achieve the CCA (Climate Change Agreement) target of an 80\% reduction in $\mathrm{CO}_{2}$ emissions from 1990 levels, which is used as the baseline, by 2050 [3].

Over the past few decades, considerable research activities have been devoted to improving the use of renewable energy resources. Solar energy is one form of renewable energy that has great potential. Two main applications of solar energy are for electricity generation (via concentrating solar thermal power (CSP) and solar photovoltaic (PV) systems ) and for solar heating and cooling (SHC) applications [4].

Solar Water Heating Systems (SWHS) are one of the technologies being developed for SHC applications. In solar water heating systems, the Sun's energy is used to produce DHW. It is particularly appropriate for existing dwellings where heating system improvements are already being undertaken and space is available for a solar collector to be fitted on the roof.

Solar water heating systems are amongst the most cost-effective renewable energy systems for many climates providing an alternative to or supplementing conventional domestic energy systems using fossil fuel. During the summer months, a typical solar hot water system can supply between 80 and 100 per cent of hot water demand [5]. This will be considerably less in winter. The capital cost of installing solar water heating (compared to conventional forms of domestic water heating) is relatively high; however, this cost can be recouped through reduced fuel bills [6]. 
Solar energy is a natural source of energy, but it is intermittent, transient and unpredictable in nature. Because of the variable intensity and intermittent nature of solar energy across a given interval of hours, days, and seasons, various practical problems arise. This creates a demand for an effective subsystem which is capable of storing thermal energy when available solar energy exceeds demand to allow it to be used during the night or periods of low insolation. A similar problem arises for waste heat recovery systems where availability of waste heat and period of use are not concurrent, creating a need for thermal energy storage (TES) to enable waste heat utilisation [7].

The general operation of any thermal energy storage (TES) system comprises three stages: charging, storing and discharging. There are three main types of TES systems, i) sensible (liquid or solid medium), ii) latent (heat of fusion) and ii) thermochemical (a reversible chemical reaction) [8]. The selection of TES approach is dependent on many factors including the storage period required, i.e. hours, days, weeks, interseasonal, operating temperatures, economic viability, operating conditions, etc [9]. To date, most thermal storage facilities use sensible heat storage by changing the temperature of a storage medium (such as water, air, oil, rock beds, bricks, concrete or sand) [10]. The use of latent heat thermal energy storage is a particularly attractive approach because it provides a high energy storage density when a narrow operational temperature is required. When compared to a sensible heat energy storage system, a latent heat energy storage system requires a smaller weight and volume of material for a given amount of thermal energy storage if the charge/discharge temperatures are close to the phase transition temperature [10-16]

The large range of commercially available Phase Change Materials (PCMs) with different phase transition temperatures allows the selection of the most suitable PCM for specific application requirements. Depending on application temperature requirements, PCMs can be divided into three main groups based on the temperature ranges over which the TES phase transition occurs:

(i) low-temperature PCMs with phase transition temperatures below $15^{\circ} \mathrm{C}$, usually used in air conditioning applications and the food industry,

(ii) mid-temperature PCMs, with phase transition temperatures in the range, $15-90{ }^{\circ} \mathrm{C}$ used in domestic solar heating applications, heating and cooling applications in buildings, textiles, electronics and medical devices, and 
(iii) high-temperature PCMs with a phase transition above $90{ }^{\circ} \mathrm{C}$ developed mainly for aerospace and industrial applications[17].

An effective design of LHTESS requires the following: (i) a PCM suitable for the desired temperature range; (ii) a container to enclose the PCM[18-21] (iii) a heat exchange surface to transfer heat from a heat source to the PCM and from the PCM to the heat sink $[21,22]$.

A review of experimental studies of LHTESS shows that the thermal performance of the LHTESS depends on the thermophysical properties of the PCM and the design of the heat exchange [23]. There must be an appropriate rate of heat exchange between the PCM and HTF during charging and discharging for the store to function effectively and high energy storage efficiency so that good performance can be achieved. PCM based stores typically require large heat transfer surface areas and/or high convective heat transfer coefficients between the PCM (encapsulated or enclosed) and the HTF [24].

Of the different designs of LHTESS studied, over $70 \%$ of papers relate to shell and tube systems. This is probably due to the facts that (i) most engineering systems employ cylindrical pipes and (ii) heat loss from a shell and tube system is minimal [10].

When designing a LHTESS, for example in residential applications different factors must be considered [25], for example:

a) the LHTESS charging/discharging time, which plays a vital role in determining the functionality of the system,

b) the fabrication cost, a simple design using small amounts of materials can help minimise fabrication costs,

c) storage system compactness, allowing stores to be used when space costs are high or available space is limited,

d) high round trip efficiency, reducing parasitic heat losses to ambient,

e) high overall heat transfer rate between the HTF and the PCM, allowing good power levels to be achieved during charging and discharging, and

f) the pressure drop developed due to frictional losses within the heat exchanger, increasing pumping power requirements. 
The key performance indicators for thermal energy storage systems are defined by the energy storage density and the effectiveness of the heat transfer [26]. N.H.S. Tay et al [26]developed a simplified method for the characterisation of phase change thermal energy storage systems using the $\mathcal{E}$-NTU technique. Their results show that this technique can readily be used as a design tool for sizing and optimizing a thermal energy storage unit using phase change materials. The same authors performed an experimental investigation of a thermal energy storage system with coils of a tube inside a PCM filled cylindrical tank. This investigation utilised four tubes coiled inside a $290 \mathrm{~mm}$ diameter by $330 \mathrm{~mm}$ high cylindrical tank containing $27.6 \mathrm{~kg}$ of water as a PCM. They found that increasing the HTF mass flow rate from $0.01 \mathrm{~kg} / \mathrm{s}$ to $0.07 \mathrm{~kg} / \mathrm{s}$ reduced the period of phase transition from $215 \mathrm{~min}$ to $88 \mathrm{~min}$.

Z.N. Meng and P. Zhang [27] conducted an experimental and numerical investigation of the melting behaviour of composite PCM fabricated by embedding copper foam into paraffin wax in a tube-in-tank latent heat thermal energy storage system (LHTESS). The copper foam had a porosity of $95.0 \%$ and a pore size of $10 \mathrm{PPI}$. The melting temperature range of the paraffin used was within the range from $54.43-64.11^{\circ} \mathrm{C}$, and the latent heat was approximately 175,240 $\mathrm{J} / \mathrm{kg}$. It was found that the temperature in the top region of the tank was higher than in other regions due to natural convection during charging. The melting time reduced by $42.7 \%$ when the HTF inlet temperature was increased from $70{ }^{\circ} \mathrm{C}$ to $80{ }^{\circ} \mathrm{C}$. An increase in HTF velocity from $0.1 \mathrm{~m} / \mathrm{s}$ to $0.2 \mathrm{~m} / \mathrm{s}$ reduced the time required for melting by only $15.1 \%$.

The melting and solidification processes of paraffin wax in a horizontal double pipe latent heat energy storage system were investigated experimentally by S.P. Jesumathy et al [28]. Their results indicated that a paraffin wax with a phase transition temperature range of 58-60 ${ }^{\circ} \mathrm{C}$ is a suitable candidate for storing thermal energy in solar water heating applications and that the effects of changes in operating conditions of the HTF mass flow rate and inlet temperature are more pronounced during melting than during solidification. Likewise, S. Seddegh et al [29] carried out both an experimental and numerical investigation into the heat transfer in a vertical cylindrical shell-and-tube LHTES unit during both the charging and discharging processes. The PCM used in the test was RT60 paraffin wax from Rubitherm [30]. Their results showed that during the charging process, a confined vertical liquid PCM layer formed around the HTF pipe once melting commenced. Subsequently, the heat was transferred by natural convection and the liquid PCM rose to the upper section of the storage container. During the discharging 
process, their results demonstrated that the solidification front moved along both radial and axial directions at the same time.

C. Liu and D. Groulx [31] presented an experimental study of the phase change heat transfer inside a horizontal shell-and-tube latent heat energy storage system (LHTESS), designed with four longitudinally finned copper pipes running the length of the cylindrical container. The longitudinal fins were installed in two orientations (vertical fins and angled fins). Dodecanoic acid, also known as lauric acid, was selected $\left(\mathrm{T}_{\text {melt }}=43.5^{\circ} \mathrm{C}\right)$. It was observed that during the initial stage of charging, conduction was the dominant heat transfer mechanism with natural convection dominating when sufficient liquid PCM was present inside the store. During the solidification process conduction was the dominant heat transfer mechanism. When comparing both fin configurations, it was found that with a HTF inlet temperature of $50{ }^{\circ} \mathrm{C}\left(\mathrm{T}_{\text {melt }}=43.5\right.$ ${ }^{\circ} \mathrm{C}$ ), angled fins resulted in a slightly lower complete melting time compared to vertical fins.

The development of a simple and low-cost latent heat storage unit for domestic hot water applications, which can easily be integrated with existing solar heating systems or heat pump systems without major system modification is required. The main focus of the present experimental study was to develop a novel latent heat storage system for DHW applications and examine its performance during both charging (melting process) and discharging (solidification process). A series of experiments have been conducted to study the effect of the volume flow rate and temperature of the HTF on the melting and solidification of paraffin wax (RT44HC) and the quantity of thermal energy stored. The PCM was contained in a cuboidshaped store with a vertically oriented multi-pass tube heat exchanger. The transient variations of temperature distribution in selected horizontal and vertical planes within the latent heat storage system have been measured to understand the heat transfer within the latent heat thermal energy storage unit.

\section{Experimental set-up and methodology of tests}

\subsection{System description}

For the present study, a pilot plant test facility was designed and constructed at Loughborough University to investigate the charging and discharging process of a LHTESS. A schematic diagram of the experimental system used to evaluate the performance of LHTESS is presented in Fig. 1. The system was comprised of three main parts, the storage system, the 
cooling system and the heating system. The storage system consisted of a latent heat storage tank filled with PCM, thermocouples to monitor the PCM's temperature, a data logger and a computer. The thermal store was a cuboid shape with the outer shell made of $20 \mathrm{~mm}$ polycarbonate sheet $\left(k=0.2 \mathrm{~W} / \mathrm{m} .{ }^{\circ} \mathrm{C}\right), 560 \mathrm{~mm}$ in length, $610 \mathrm{~mm}$ in height and $400 \mathrm{~mm}$ in width providing a volume of $120 \mathrm{~L}$. A vertically-oriented multi-pass copper tube heat exchanger with a length of $30.0 \mathrm{~m}$, fabricated from $15 \mathrm{~mm}$ OD and $1 \mathrm{~mm}$ wall thickness copper tube was immersed in the storage tank. The heat exchanger had 4 passes with 24 turns on each pass, the heat exchanger inlet and outlet were both located on the top of the thermal store.

The cooling and heating systems contain two $250 \mathrm{~L}$ hot and cold-water storage cylinders [32] with heat exchange fluid water circulated through a closed dynamic temperature control system (Peter Huber Kältemaschinenbau, Germany, type: Unistat 510w [33]) to provide cooling or heating during charging and discharging. External Pt100 sensor probes were used to set the temperature in the tank to the required HTF temperature. The circuit contains a series of flow control valves and circulation pumps (Pedrollo PQm, $0.37 \mathrm{KW}$ [34]) utilised to circulate and control the direction of HTF flow between the hot and cold water tanks and the LHTESS. A turbine pulse flow rate sensor (Gems ${ }^{\mathrm{TM}}$ FT-110 Series, Hall effect [35]) was employed to measure the volume flow rate of the HTF with an accuracy of $\pm 3 \%$ of the reading. The accuracy of the flow rate sensor was confirmed by measuring the time required to fill a 10-litre container using different flow rates.

Thirty T-type thermocouple probes $\left(\boldsymbol{T}_{1}-\boldsymbol{T}_{30}\right)$ (accuracy $\pm 0.2{ }^{\circ} \mathrm{C}$ ) were located in the PCM store as shown in Fig.2. These thermocouples were used to provide qualitative information on the temperatures and the phase change process within the thermal storage system. Two additional PT1000 sensors (with an error in temperature of $< \pm 0.1^{\circ} \mathrm{C}$ ) were located at the inlet and the outlet of the heat exchanger to measure the inlet and outlet temperature of the HTF. The first thirty thermocouples were located in a $3 \mathrm{~d}$ grid pattern at five heights (The vertical distance between each thermocouple at each location was $100 \mathrm{~mm}$ ) in six different zones (referred to as $\mathbf{A}, \mathbf{B}, \mathbf{C}, \mathbf{D}, \mathbf{E}$ and $\mathbf{F}$ ) as shown in Fig.2. The spatial distribution of the vertical and horizontal locations of the thermocouple probes was selected within the PCM store to provide measurements of the PCM temperature over the full three-dimensional body of the store. 
Thermocouple probe $\boldsymbol{T}_{31}$ was located at the bottom of the tank, near to the edge to provide an indication of the state of charge of the store; being at the very bottom of the tank, when $\boldsymbol{T}_{31}$ recorded temperatures above the PCM melting temperature, the entire PCM in the tank is liquid. Thermocouple probe $\boldsymbol{T}_{32}$ was used to record the ambient temperature.

A data logger (Datataker DT85 [36]) was used to record the volume flow rate and thermocouple readings and transfer the collected data to a computer. Temperatures were recorded during the melting process at five seconds intervals. $d E X ®$ Logger Software was used to record data and display the results on the computer screen updated every five seconds. The capital costs of the experimental LHTESS tested are presented in Table 1.

Table 1. The capital cost of the experimental LHTESS

\begin{tabular}{|l|l|l|}
\hline Paraffin wax (RT44HC) & $80 \mathrm{~kg} \times 12.64(£ / \mathrm{kg})$ & $£ 1011.2$ \\
\hline Copper Tube & $30 \mathrm{~m} \times 2.16(£ / \mathrm{m})$ & $£ 64.80$ \\
\hline $90^{\circ}$ bend Copper tube & $100 \times 0.21$ & $£ 21.0$ \\
\hline Polycarbonate tank & $120 \mathrm{~L}$ & $£ 300.0$ \\
\hline Labour & $10 \mathrm{~h} \times 9.0(£ / \mathrm{h})$ & $£ 90.0$ \\
\hline Total capital cost (per store) & & $£ 1487.0$ \\
\hline
\end{tabular}




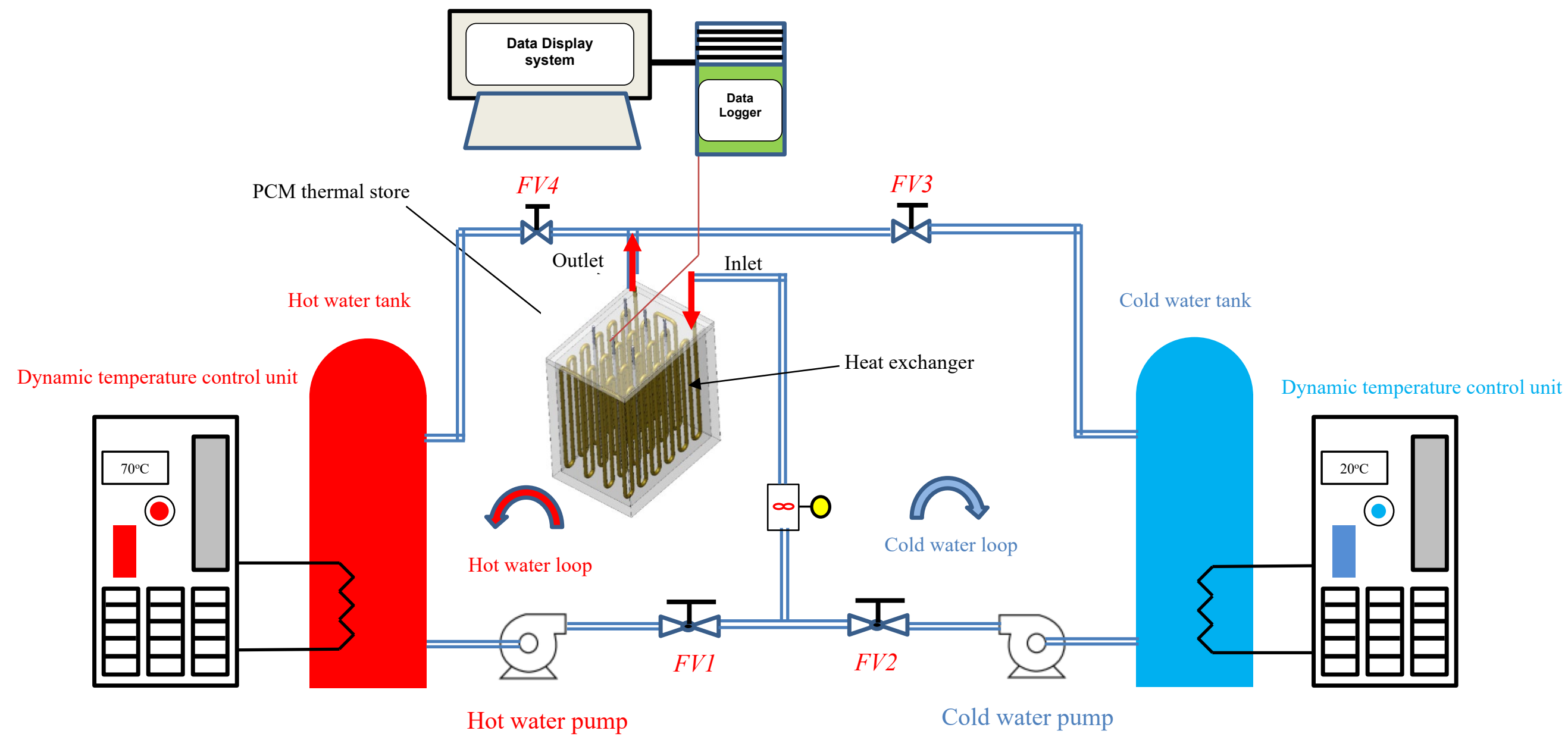

Fig.1 Diagram illustrating key components of the experimental apparatus developed to assess charging and discharging of a LHTESS. 

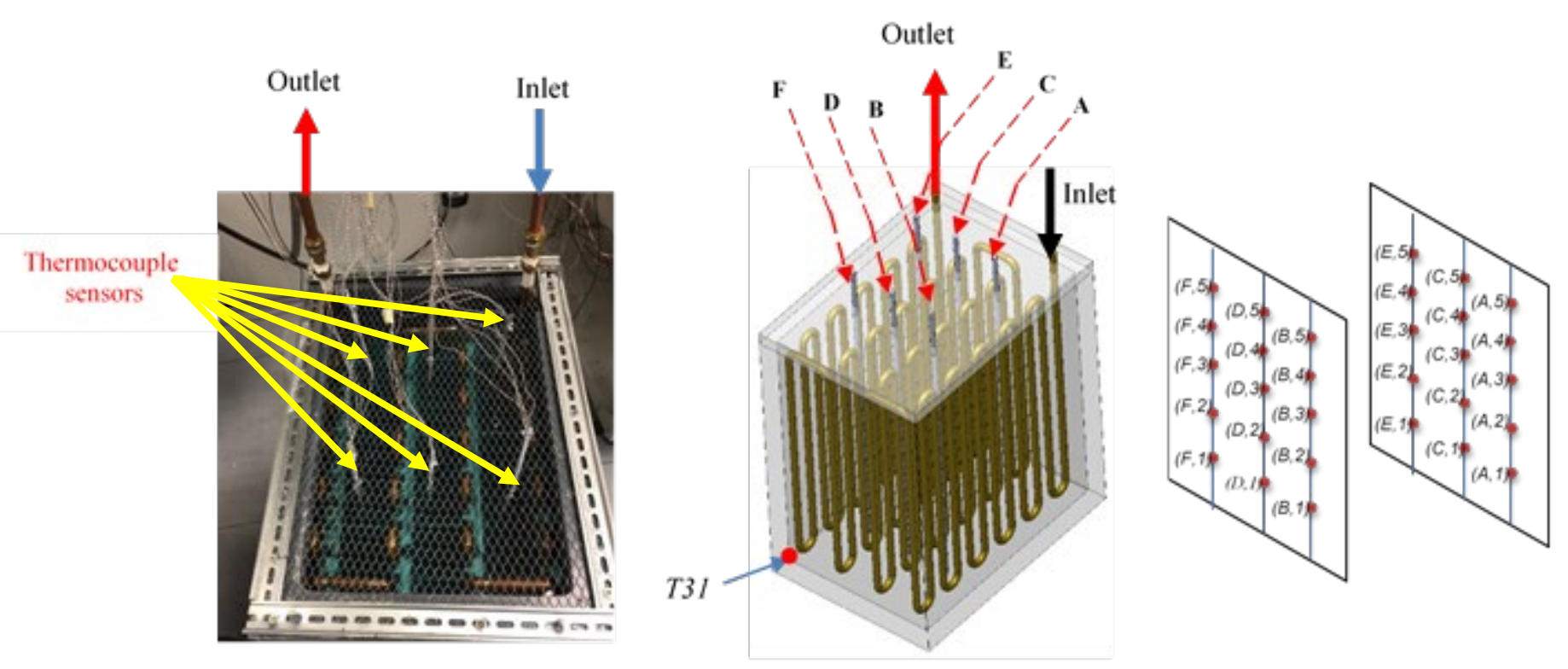

Fig.2 Prototype LHTESS and an illustration to show the horizontal and vertical locations of the thermocouples in zones $\mathbf{A}, \mathbf{B}, \mathbf{C}, \mathbf{D}, \mathbf{E}$ and $\mathbf{F}$.

\subsection{Phase change material selection}

For a solar domestic hot water (SDHW) system, a suitable melting temperature range for a $\mathrm{PCM}$ was determined to be $42^{\circ} \mathrm{C}$ to $48^{\circ} \mathrm{C}$ [31]. Based on this phase change temperature range, the PCM store was filled with $80 \mathrm{~kg}$ of paraffin wax (RT44HC). RT44HC a commercially available material (Rubitherm GmbH-Germany)[30] was used because it has a high heat storage capacity over a narrow temperature range which makes it suitable for solar energy, domestic hot water and space heating applications. It is also chemically stable, does not degrade over multiple cycles, is non-corrosive, and non-toxic.

In order to determine the specific heat capacity of the PCM during the melting process, measurements were performed using a TA Instruments Differential Scanning Calorimeter (DSC[37]) with Refrigerated Cooling System (RCS 90) [38]. The measurements were performed with heating/cooling rates of $1.0^{\circ} \mathrm{C} / \mathrm{min}, 5^{\circ} \mathrm{C} / \mathrm{min}$ and $10^{\circ} \mathrm{C} / \mathrm{min}$ and a temperature range from $20-70{ }^{\circ} \mathrm{C}$. The measured temperature enthalpy curve recorded during the melting process for RT44HC is shown in Fig.3. The heating rate curves obtained by DSC for RT44HC have two-phase change peaks near $40.5{ }^{\circ} \mathrm{C}$ and $43.0^{\circ} \mathrm{C}$. The first small peak represents a solidsolid phase change and the second larger peak represents a solid-liquid phase change. The measured latent heat was $218.11 \mathrm{~kJ} / \mathrm{kg}$ for a heating rate of $1.0^{\circ} \mathrm{C} / \mathrm{min}$. This value nearly matches the value indicated by [39] ( $226 \mathrm{~kJ} / \mathrm{kg}$ ). The measured values of specific heat capacity versus temperature are provided as supplementary material [1]. Other thermophysical properties of RT44HC were obtained from the manufacturer's datasheet [30] and are presented in Table 2. 


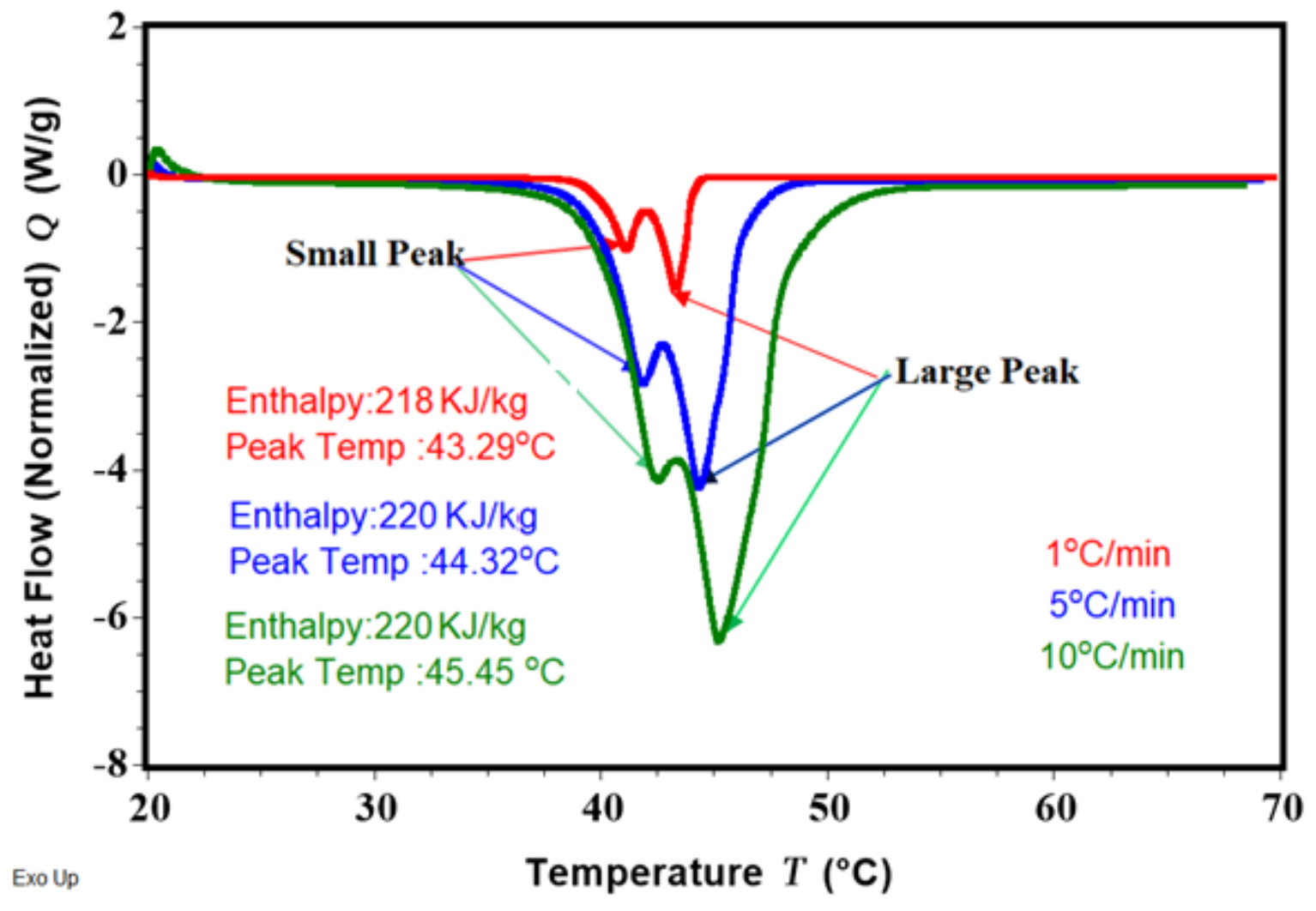

Fig 3. The measured temperature enthalpy curve for RT44HC

Table 2 Thermophysical properties of paraffin wax RT44HC [30].

\begin{tabular}{|l|l|}
\hline Thermal conductivity $\left(k_{s}\right)$ & $0.2 \mathrm{~W} / \mathrm{m}^{\circ} \mathrm{C}$ \\
\hline Thermal conductivity $\left(k_{\text {liq }}\right)$ & $0.2 \mathrm{~W} / \mathrm{m}^{\circ} \mathrm{C}$ \\
\hline Density: solid phase $\left(\rho_{s}\right)$ & $800 \mathrm{~kg} / \mathrm{m}^{3}$ \\
\hline Density: liquid phase $\left(\rho_{\text {liq }}\right)$ & $700 \mathrm{~kg} / \mathrm{m}^{3}$ \\
\hline Volumetric expansion coefficient $(\beta)$ & $0.00259^{\circ} \mathrm{C}^{-1}$ \\
\hline Dynamic viscosity $\left(\mu_{\text {liq }}\right)$ & $0.008 \mathrm{~kg} / \mathrm{m} \mathrm{s}$ \\
\hline
\end{tabular}

\subsection{Calculation methods and data analysis}

\subsubsection{Mean power and energy stored}

The total power input/output to the PCM is equal to the energy input /output from the hot/cold HTF assuming that there is negligible heat loss from the store.

$\dot{Q}_{\text {input } / \text { output }}=\dot{m} C_{\text {,water }}\left(T_{\text {in }}-T_{\text {out }}\right)$ 
Where $\dot{m}$ is the mass flow rate of the HTF, $C_{p \text {,water }}$ is the specific heat capacity of water evaluated at the average temperature of the $\mathrm{HTF}$, and $T_{\text {in }}, T_{\text {out }}$ are the inlet and outlet temperatures of the HTF, respectively.

The cumulative energy input to the store ( $Q_{\text {cumulative }}$ ) was calculated by summing the energy delivery to the store over (evaluated for each time period between readings) the time required for charging/discharging as given by Eq (2):

$Q_{\text {cumulative }}=\sum_{i=0}^{i=n} \Delta t \dot{m} C_{p, \text { water }}\left(T_{\text {in }}-T_{\text {out }}\right)$

To verify the calculations of energy stored/recovered, they were compared to the theoretical energy storage capacity of the PCM. The theoretical heat storage capacity of the unit was determined taking account of both sensible and latent heat components calculated using Eq (3):

$$
Q_{\text {stored }}=m_{p c m}\left[C_{p, p c m, s}\left(T_{m}-T_{i}\right)+\Delta h_{m}+C_{p, p c m, l}\left(T_{f}-T_{m}\right)\right]
$$

Where $\mathrm{m}$ is the mass of the PCM in the LHTESS, $C_{p, s}$ and $C_{p, l}$ are the specific heat capacities for the solid and liquid PCM, $T_{m}$ is the melt temperature of the PCM, $T_{i}$ and $T_{f}$ are the initial and final temperature of the PCM in the store.

\subsection{Uncertainty analysis}

To estimate the uncertainty in the results, the uncertainties in the primary measurements were determined. An experimental uncertainty analysis was then performed based on the methods described in [40]. Assuming that the final results are derived from independent variables $y_{1}, y_{2} \ldots, y_{n}$. The uncertainty of result $W$ is obtained by combining the uncertainty of the independent variables $W\left(y_{i}\right)$ as follows:

$$
\begin{aligned}
& K=f\left(y_{1}, y_{2}, \ldots, y_{n}\right) \\
& W(K)=\sqrt{\sum_{i=1}^{n}\left(\frac{\partial f}{\partial y} W\left(y_{i}\right)\right)^{2}}
\end{aligned}
$$

The uncertainty in the cumulative stored energy was calculated as follows

$$
W(Q)=t C_{p, H T F} \sqrt{\left(\Delta T W_{\dot{m}}\right)^{2}+\left(\dot{m} W_{T_{\text {out }}}\right)^{2}+\left(-\dot{m} W_{T_{\text {in }}}\right)^{2}}
$$

Where $W_{\dot{m}}$ is the uncertainty in the flow meter measurement, $W_{T_{\text {out }}}$ and $W_{T_{\text {in }}}$ are the uncertainties in the measurements of HTF outlet and inlet temperatures, respectively. 
The expected uncertainties in the calculated results, as well as the uncertainties associated with the thermophysical properties of the HTF and PCM are presented in Table 3.

Table 3 Uncertainties of the measured and calculated variables

\begin{tabular}{|l|c|}
\hline Variables & Uncertainty \\
\hline PCM mass & $\pm 1.0 \%$ \\
\hline PCM temperature & $\pm 2.0 \%$ \\
\hline Temperature difference $\left({ }^{\circ} \mathrm{C}\right)$ & $0.2{ }^{\circ} \mathrm{C}$ \\
\hline Flow rate & $\pm 1.0 \%$ \\
\hline PCM accumulated Energy & $\pm 2.5 \%$ \\
\hline
\end{tabular}

\section{PCM store charging and discharging experiments}

Charging and discharging tests were performed for different HTF inlet temperatures and volume flow rates. Hot and cold-water storage tanks were employed to provide constant temperature hot and cold fluid for the charging and discharging processes, respectively. The flow direction of the HTF was controlled by valves which provided the ability to easily switch between charging and discharging. Prior to charging the PCM store, the HTF in the hot water tank was heated using a dynamic temperature control system to the set specific temperature. The charging process was initiated by starting the circulation pump and setting the desired water volume flow rate using the valve $F V-1$ and the flow meter. Valve $F V-2$ and $F V-3$ were closed, valve $F V$-4 was open to protect the pump and ensure a closed-loop configuration. Temperatures within the store were recorded by the data acquisition system.

Once the charging cycle was complete, a discharging cycle was initiated after setting the flow rate and desired discharge temperature. Valves $F V-1$ and $F V-4$ were closed and valves $\mathrm{FV}-2$ and $\mathrm{FV}-3$ opened and set to maintain a constant specific volume flow rate of cold water to the store during the discharging test. Data acquisition was continued until the PCM and outlet water achieved the same temperature and discharging was complete.

\section{Results and discussion}

\subsection{Reliability and repeatability}

Several controlled preliminary tests were undertaken to ensure the consistency of experimental results, a series of five charging cycle experiments were performed with a constant inlet temperature of $70{ }^{\circ} \mathrm{C}$ and volume flow rate of $10.0 \mathrm{~L} / \mathrm{min}$. Temperatures measured by three thermocouples inside the PCM store $\left[\boldsymbol{T}_{(A, 1)}, \boldsymbol{T}_{(C, 3)}\right.$ and $\left.\boldsymbol{T}_{(D, 4)}\right]$ and the average 
temperature of the PCM calculated from all temperatures measured within the PCM store during these tests are plotted in Fig.4 and Fig.5. Based on the experimental measurements presented in Fig.4 and Fig.5, the experimental setup clearly produced repeatable results. Due to a slight variation in initial LHTESS and inlet HTF temperatures, there are small variations in temperature measured during sensible heating of the PCM when in the solid phase.
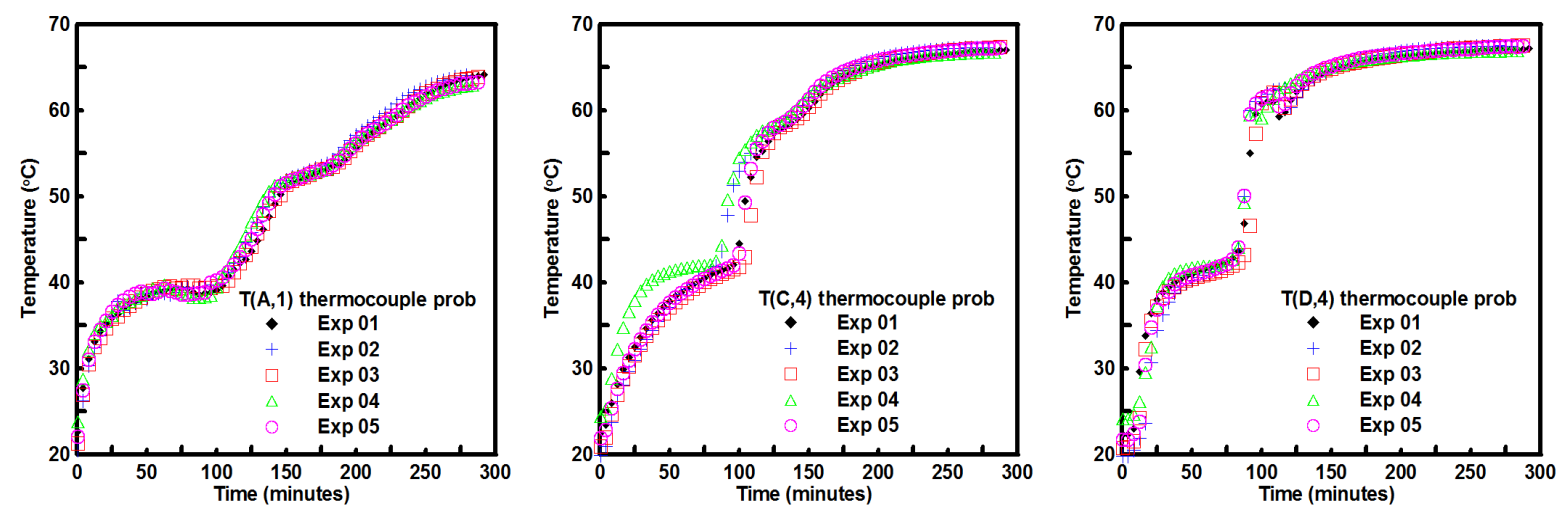

Fig.4. Temperatures measured with time at three different locations $\boldsymbol{T}_{(A, 1)}, \boldsymbol{T}_{(C, 3)}$ and $\boldsymbol{T}_{(D, 4)}$ during the PCM charging process $\left(T_{\text {inlet }}=70{ }^{\circ} \mathrm{C}\right.$ and volume flow rate $\left.=10.0 \mathrm{~L} / \mathrm{min}\right)$.

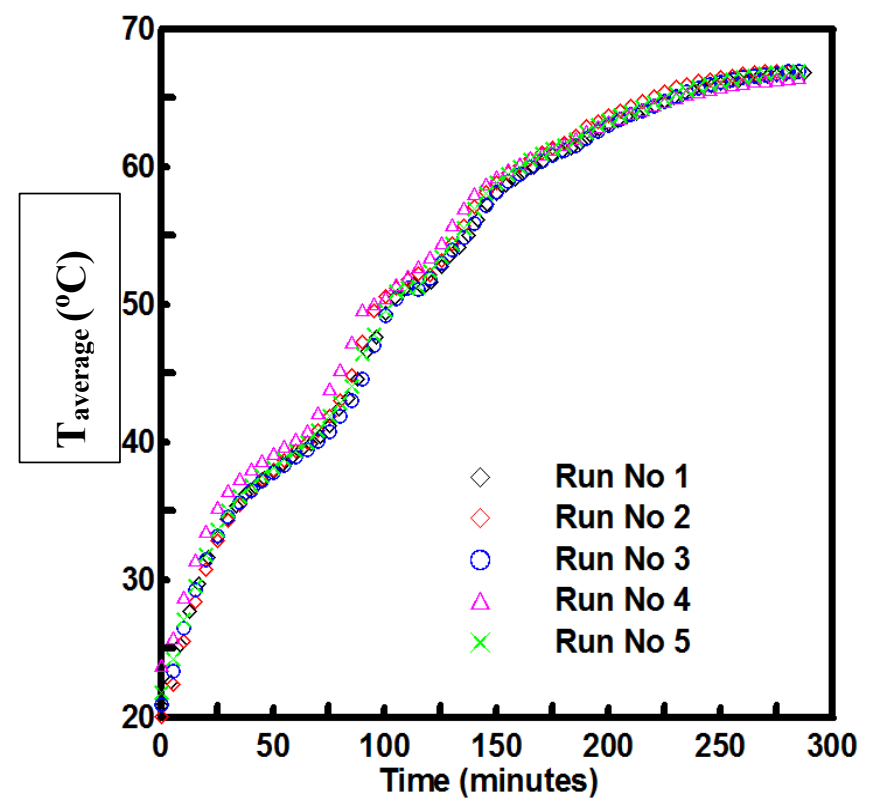

Fig.5. Average measured PCM temperatures during five-store charging experiments using a constant inlet fluid temperature of $70^{\circ} \mathrm{C}$ and a volume flow rate of $10.0 \mathrm{~L} / \mathrm{min}$.

\subsection{Charging mode}

For charging experiments, the initial temperature of the LHTESS was allowed to cool to the ambient temperature, around $22{ }^{\circ} \mathrm{C}$. The charging process commenced when the measured 
temperature difference between all thermocouples within the store was less than $1^{\circ} \mathrm{C}$ and ended when the reading of thermocouple $\boldsymbol{T}_{31}$ increased to $50{ }^{\circ} \mathrm{C}$.

\subsubsection{Zonal temperature distribution}

In order to evaluate the transient temperature distribution development within the PCM in the LHTESS, the temperature was recorded at all thirty thermocouples installed within the LHTESS every 5 seconds (five vertical positions in six zones). The transient temperature distribution can help to identify the location of the phase transition front and the heat transfer rates within the LHTESS. During the charging cycle, the HTF from the how water storage tank at $80{ }^{\circ} \mathrm{C}$ was circulated through the heat exchanger in the LHTESS with a volume flow rate of $2.5 \mathrm{~L} / \mathrm{min}$.

Fig.6. shows the temperature variation with time measured at selected locations in the LHTESS during charging. It is evident from the measured temperatures that due to the small specific heat capacity of the solid PCM a linear rise in temperature from the initial value $22{ }^{\circ} \mathrm{C}$ to about $41{ }^{\circ} \mathrm{C}$, just below the phase change temperature is determined by conduction heat transfer within the PCM. Subsequently, due to the high latent heat capacity, a comparatively slow and gradual increase in PCM temperature from $41{ }^{\circ} \mathrm{C}$ to $44{ }^{\circ} \mathrm{C}$ was measured. During this stage, as temperature increases, the phase transition of PCM from solid to mushy to liquid phase takes place. After phase change, a rapid rise in the PCM temperature occurs, which corresponds to sensible thermal energy storage in the liquid PCM.

It can be observed from Fig.6. that due to the higher temperature difference between the HTF temperature and the PCM, the time for phase transition in zones (A) and (B) are significantly shorter compared to other zones. Phase transition in the top of zones (A) and (B) occurs at approximately 25 minutes, whereas temperatures measured in other zones indicate the PCM is still in the solid phase. It can also be seen from Fig.6. that 75 minutes into the charging cycle, the temperatures measured by the upper thermocouples in zones (A) and (B) indicate that the PCM is liquid, while in zones (C), (D), (E) and (F) the PCM is still in the mushy or solid phase. The PCM at the top of zones (A) and (B) melts quickly due to the high temperature of the HTF, combined with, the buoyancy effect due to volumetric expansion leading to natural convection causing the melted liquid PCM to rise to the top of the store.

From Fig.6. after 100 minutes, it can be seen from measured temperatures that the central positions of zones (A), (B) and (C) are in the liquid phase, whereas zones (D), (E) and (F) are 
still in the mushy phase. Due to natural convection liquid PCM adjacent to the heat transfer surface in the central and bottom regions rises due to buoyancy. Due to natural convection the measured PCM temperatures at the top positions will for this heat exchanger configuration, always be higher compared to those at the central and bottom positions.

From Fig. 6 it can be seen that the phase transition rate at the top of all the zones is fairly similar, the phase transition rate in the central positions of zones (A), (B) and (C) is $67 \%$ higher compared to that within zones (D), (E) and (F). This is due to the temperature gradient between the HTF and PCM in zones (A), (B) and (C) being higher with greater heat transfer than in zones (D), (E) and (F). The phase transition rate at the bottom locations in zones (A), (B) and (C) is higher compared to the other zones.

From Fig. 6 it can be seen that the time required for phase transition at the top of all the zones is fairly similar, the time required for phase transition in the central positions of zones (D), (E) and (F) is $67 \%$ greater compared to that within zones $(\mathbf{A}),(\mathbf{B})$ and $(\mathbf{C})$. This is due to the temperature gradient between the HTF and PCM in zones (A), (B) and (C) being higher leading to greater rates of heat transfer than in zones (D), (E) and (F). The time required for phase transition at the bottom locations in zones $(\mathbf{A}),(\mathbf{B})$ and $(\mathbf{C})$ is shorter compared to the other zones.

The temperature variation with time of the upper-level thermocouple measurements, $\boldsymbol{T}_{(A, 5)}$, $\boldsymbol{T}_{(B, 5)}, \boldsymbol{T}_{(C, 5)}, \boldsymbol{T}_{(D, 5)}, \boldsymbol{T}_{(E, 5)}$ and $\boldsymbol{T}_{(F, 5)}$ show an anomaly after melting, with a sudden rise and subsequent drop in temperature. A possible explanation for this is the sudden movement of hot liquid PCM upwards, which causes the sudden rise in the temperature recorded by these thermocouples with the subsequent dip in temperature resulting from mixing or entrainment and circulation of cooler liquid PCM. 

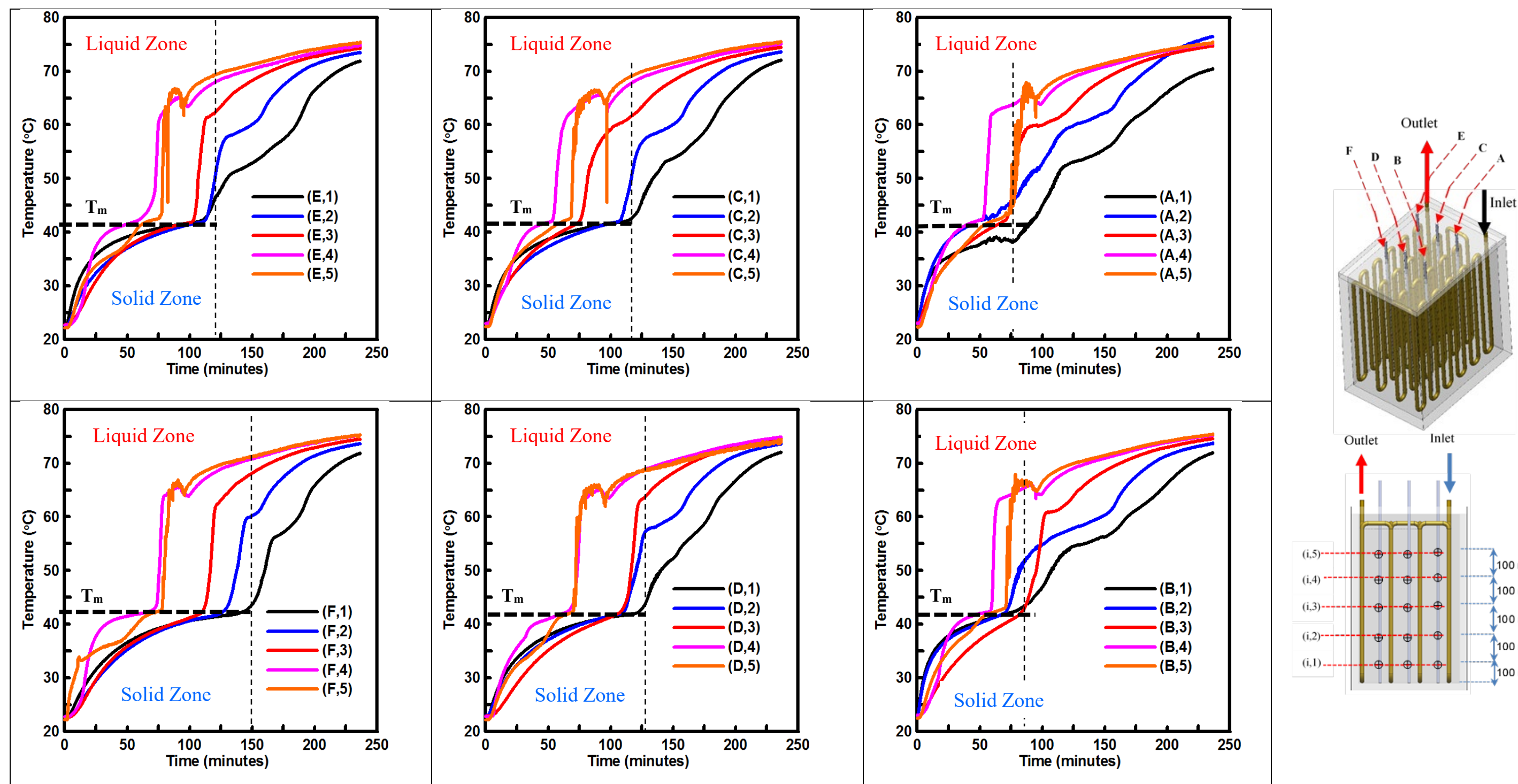

Fig. 6. Temperature profiles measured during a charging cycle at all six zones [(A), (B), (C), (D), (E) and (F)] and all five vertical positions within each zone. The HTF inlet temperature and volume flow rate were set at $80{ }^{\circ} \mathrm{C}$ and $2.5 \mathrm{~L} / \mathrm{min}$. 


\subsubsection{Effect of the volume flow rate of HTF on charging time}

A parametric investigation into the effect of HTF volume flow rate on the melting time was conducted at four HTF volume rates: $2.5 \mathrm{~L} / \mathrm{min}, 5.0 \mathrm{~L} / \mathrm{min}, 7.5 \mathrm{~L} / \mathrm{min}$ and $10.0 \mathrm{~L} / \mathrm{min}$ and at a fixed inlet temperature $70{ }^{\circ} \mathrm{C}$.

Fig.7 illustrates the HTF inlet and outlet temperature, power input, cumulative energy stored and the maximum theoretical storage capacity for each experiment. It is clear that the charging time was affected by the HTF volume flow rate.

It can be seen from Fig.7. that the HTF outlet temperature rises rapidly at first during sensible heat storage in the solid PCM, reaches a constant value for a certain period of time during latent heat storage and then increases towards the HTF inlet temperature with the remaining energy stored as sensible heat in the liquid PCM.

The experimentally determined input power rates for all tested flow rates are presented in Fig. 7 (a, c, e and g). At the start of each experiment, the inlet temperature of the HTF was approximately $70{ }^{\circ} \mathrm{C}$, while the outlet temperature was almost at the initial temperature of the PCM. The considerable difference between measured $T_{\text {in }}$ and $T_{\text {out }}$ indicates the input power at the beginning of the experiment was high, this was however due to flushing of the cold HTF out of the heat exchanger. The input power rate then decreases rapidly and reflects the heat transfer to storage. Towards the end of the tests, the input power diminishes when the PCM is all melted, and the outlet temperature stabilizes indicating a low rate of heat input.

Fig.7 (b, d, f and h) presents the cumulative heat stored for the four flow rates, obtained by summing the energy stored within each data acquisition time step. The heat stored in the LHTESS increases rapidly at the start of charging due to flushing of cold HTF from the system, a near-constant period of charging then occurs and when the temperature difference between water and PCM decreases after phase change, the heat stored increases at a reducing rate to the end of the experiment.

The calculated cumulative energy stored for this experiment was $7.8 \mathrm{kWh}$ and is closely aligned with the theoretical storage capacity of $7.85 \mathrm{kWh}$, providing confidence in the experimental results. The total charging time to bring the thermal store from an average temperature of $20 \pm 2{ }^{\circ} \mathrm{C}$ to $70 \pm 2{ }^{\circ} \mathrm{C}$ was 350 minutes for a volume flow rate of $2.5 \mathrm{~L} / \mathrm{min}$ and 300 minutes for volume flow rate $5.0 \mathrm{~L} / \mathrm{min}$. 
As seen in Fig.8, for a constant HTF temperature of $70^{\circ} \mathrm{C}$, an increase in HTF volume flow rate does not enhance heat transfer in the initial stages of the charging cycle, which is dominated by conduction in the PCM. The low thermal conductivity of the PCM in the solid phase provides high thermal resistance to heat transfer and thus limits the overall heat transfer rate. It is clear from Fig.8. that heat transfer to the PCM in the temperature range from $20{ }^{\circ} \mathrm{C}$ to $41{ }^{\circ} \mathrm{C}$ is almost the same rate for all volume flow rates. During melting of the PCM from $41^{\circ} \mathrm{C}$ to $44{ }^{\circ} \mathrm{C}$, the heat storage is strongly influenced by increasing HTF volume flow rate. As phase transition occurs and the fraction of liquid PCM increases, natural convection increases and starts to dominate the heat transfer process, with the overall thermal resistance provided by the PCM reduced. By increasing the volume flow rate, the forced convection coefficient in the heat exchanger tubes is improved, which enhances the heat transfer rate and reduces the total time required to complete the charging cycle. After the completion of melting, when sensible heating of the liquid PCM occurs, the rate of increase in temperature due to an increase in volume flow rate is insignificant.

From Fig. 8, it can be seen that at a low volume flow rate of $2.5 \mathrm{~L} / \mathrm{min}$ the PCM takes longer to melt compared to other flow volume flow rates used. Increasing the volume flow rate from $2.5 \mathrm{~L} / \mathrm{min}$ to $5.0 \mathrm{~L} / \mathrm{min}$ and $7.5 \mathrm{~L} / \mathrm{min}$ reduces the total time required for melting by $12 \%$ and $16.3 \%$, respectively. 

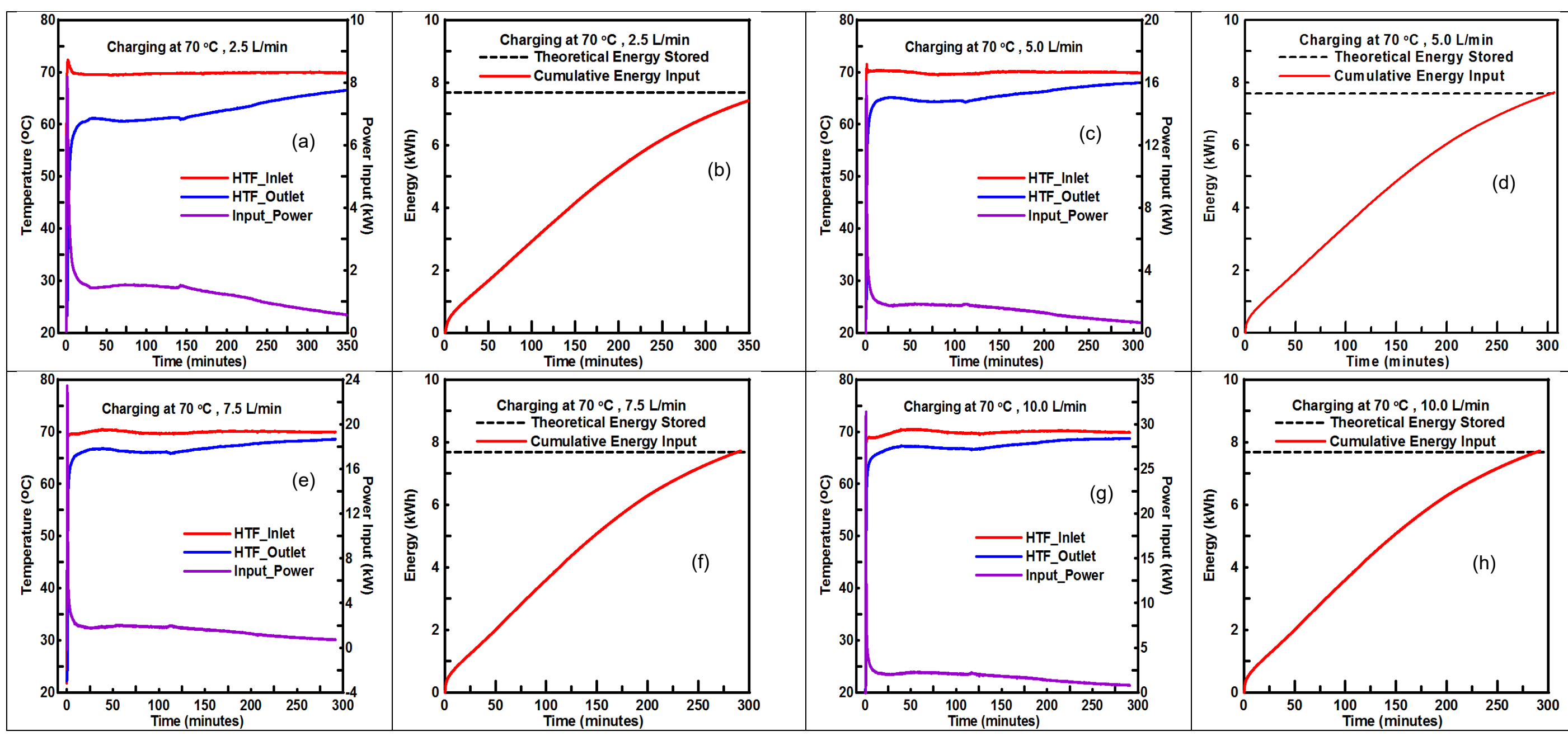

Fig.7. Power input and cumulative energy stored during charging for $\mathrm{HTF}$ inlet temperature of $70^{\circ} \mathrm{C}$ and volume flow rates $2.5 \mathrm{~L} / \mathrm{min}, 5.0 \mathrm{~L} / \mathrm{min}, 7.5 \mathrm{~L} / \mathrm{min}$ and 10.0 $\mathrm{L} / \mathrm{min}$. 

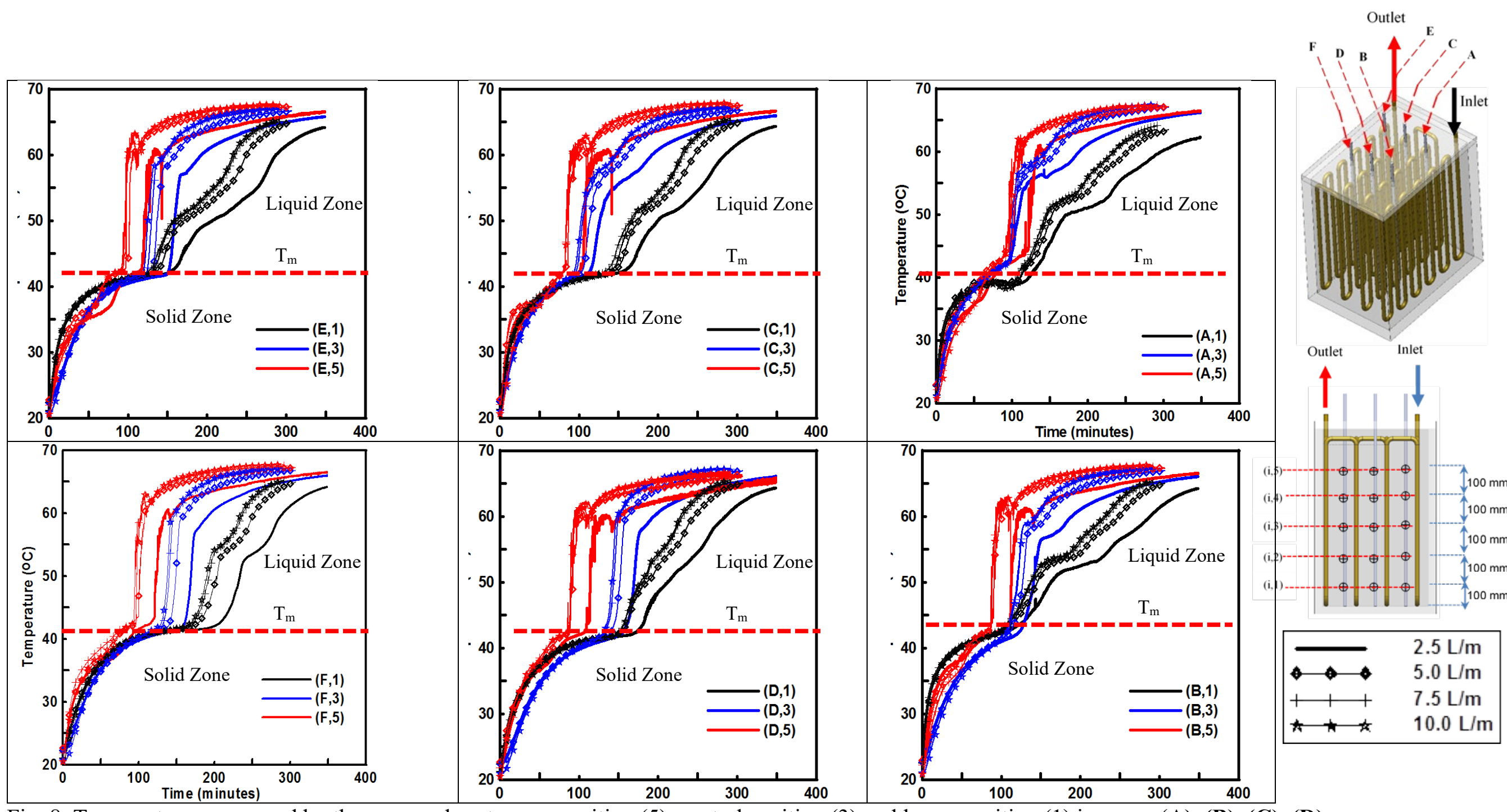
(E), and (F) during charging cycles at four different HTF volume flow rates with a constant inlet HTF temperature of $70^{\circ} \mathrm{C}$. 


\subsubsection{Effect of HTF inlet temperature on charging}

An analysis of the effect of HTF inlet temperature on the overall charging process was conducted using three inlet HTF temperatures $60{ }^{\circ} \mathrm{C}, 70{ }^{\circ} \mathrm{C}$ and $80{ }^{\circ} \mathrm{C}$. Fig. 9. presents the calculated power input, measured HTF inlet and outlet temperatures, cumulative energy stored and maximum theoretical storage capacity for each experiment. The volume flow rate used was $5.0 \mathrm{~L} / \mathrm{min}$.

A significant increase in heat transfer rate was observed when increasing the HTF inlet temperature. The higher inlet temperature provides a larger temperature difference between the HTF and the PCM. The pipe wall temperature rises more quickly transferring more heat to the PCM, which promotes faster melting at the beginning of the charging process [31].

Increasing $\mathrm{HTF}$ inlet temperature from $60{ }^{\circ} \mathrm{C}$ to $70{ }^{\circ} \mathrm{C}$ and $80{ }^{\circ} \mathrm{C}$ leads to reductions in total melting time by $44.8 \%$ and $63.7 \%$, respectively. The increase in HTF inlet temperature leads to increased sensible stored heat after phase transition resulting in an increase in the overall heat stored.

The impact of increasing the HTF inlet temperature is significant in comparison to increasing the HTF volume flow rate., i.e. increasing the Stefan number has a higher impact than increasing the Reynolds number.

Fig.10. presents the temperatures measured by selected thermocouples located in the PCM store for zones (A), (B), (C) (D), (E) and (F). The temperatures measured by each thermocouple are shown for three experiments, conducted using HTF inlet temperatures of 60 ${ }^{\circ} \mathrm{C}, 70^{\circ} \mathrm{C}$ and $80^{\circ} \mathrm{C}$. It can be seen that the thermocouples at the top positions $\left(\boldsymbol{T}_{(A, 5)}, \boldsymbol{T}_{(B, 5)}\right.$, $\left.\boldsymbol{T}_{(C, 5)}, \boldsymbol{T}_{(D, 5)}, \boldsymbol{T}_{(E, 5)}, \boldsymbol{T}_{(F, 5)}\right)$ are the first to reach the PCM melt temperature for all three HTF inlet temperatures . The thermocouples in the bottom positions $\left(\left(\boldsymbol{T}_{(A, 1)}, \boldsymbol{T}_{(B, 1)}, \boldsymbol{T}_{(C, 1)}, \boldsymbol{T}_{(D, 1)}, \boldsymbol{T}_{(E, 1)}\right.\right.$, $\boldsymbol{T}_{(F, 1)))}$ of the thermal store are the last to reach the PCM melt temperature. Thermocouples at the middle position $\left(\boldsymbol{T}_{(A, 3)}, \boldsymbol{T}_{(B, 3)}, \boldsymbol{T}_{(C, 3)}, \boldsymbol{T}_{(D, 3)}, \boldsymbol{T}_{(E, 3)}, \boldsymbol{T}_{(F, 3)}\right)$ in the store demonstrate significant variations in the measured temperature with time profile since natural convection in the liquid PCM causes the warmer liquid PCM to rise to the top of the store resulting in nearly uniform temperatures. From this figure, it can be seen that temperatures measured by thermocouples in the middle and bottom sections of the store are strongly affected by their positions relative to the HTF inlet/outlet. 


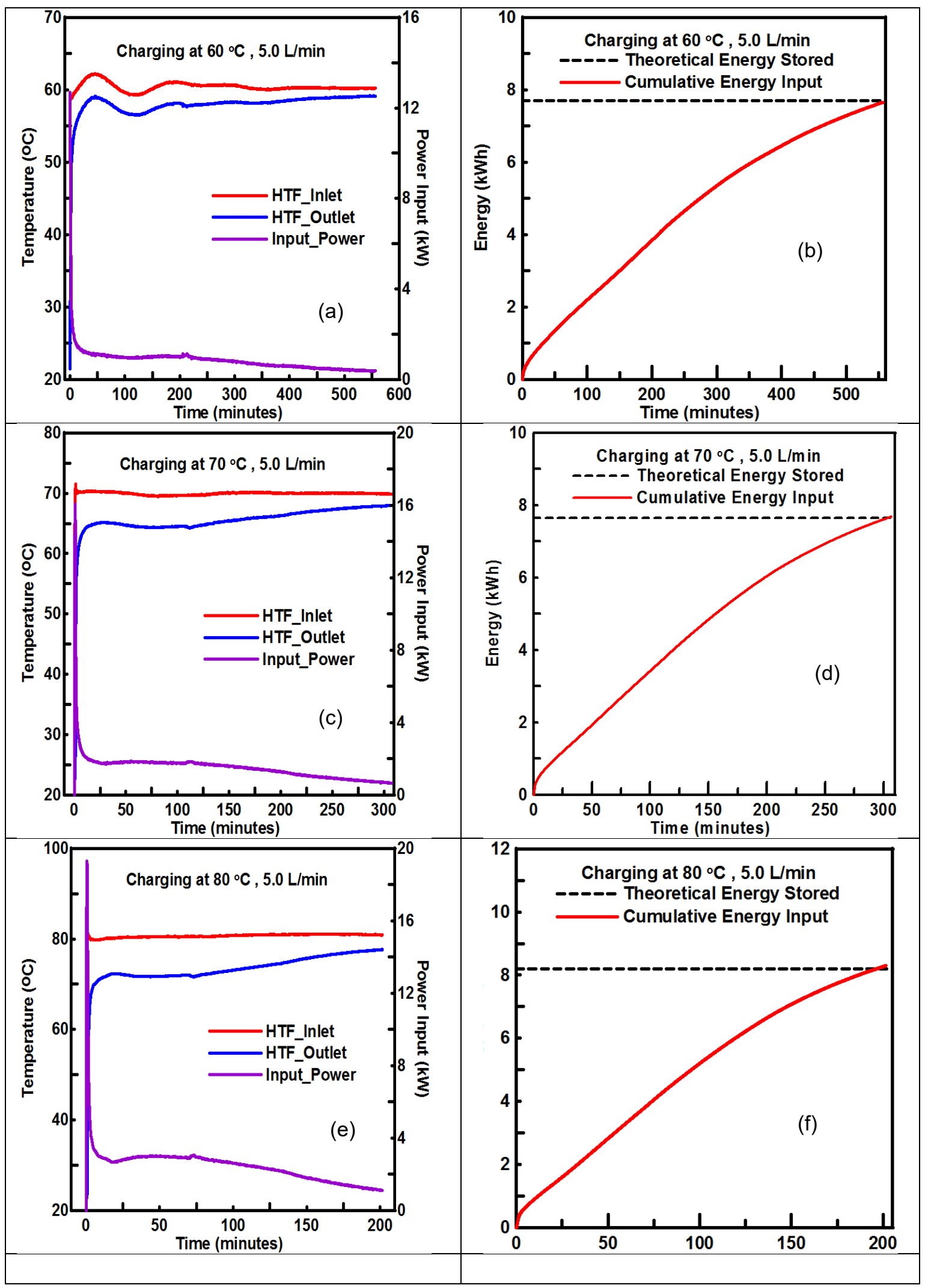

Fig.9. Power input and cumulative energy stored during charging at a volume flow rate of 5.0 $\mathrm{L} /$ min with $\mathrm{HTF}$ inlet temperatures of $60{ }^{\circ} \mathrm{C}, 70^{\circ} \mathrm{C}$ and $80{ }^{\circ} \mathrm{C}$. 

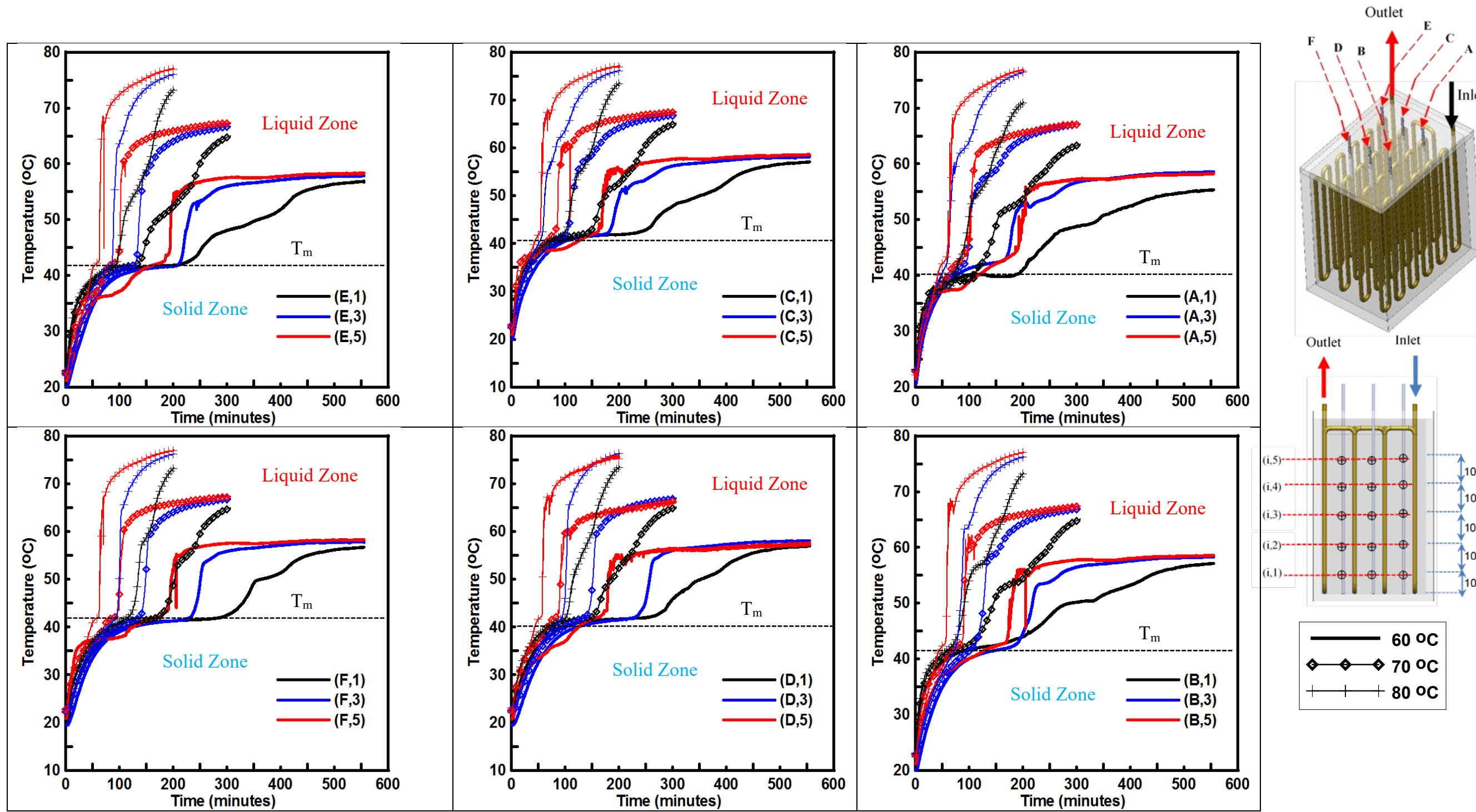

Fig. 10. Temperatures measured by thermocouples at upper position (5), central position (3) and lower position (1) of zones (A), (B), (C), (D),

(E), and (F) during the charging cycle at HTF inlet temperature of $60{ }^{\circ} \mathrm{C}, 70{ }^{\circ} \mathrm{C}$ and $80{ }^{\circ} \mathrm{C}$ and a volume flow rate $5.0 \mathrm{~L} / \mathrm{min}$. 


\subsection{Discharge mode}

To assess the thermal performance of the LHTESS during the discharging process two sets of experimental tests were conducted with a HTF inlet temperature of $22{ }^{\circ} \mathrm{C}$ and volume flow rates of $1.6 \mathrm{~L} / \mathrm{min}$ and $3.0 \mathrm{~L} / \mathrm{min}$. The initial PCM temperature in the store was above the PCM melting temperature (ranging between $65^{\circ} \mathrm{C}$ and $70^{\circ} \mathrm{C}$ ).

Due to the temperature gradient between the low-temperature HTF and the high-temperature RT44HC thermal energy is extracted from the store [41] and the temperature of the HTF increases and the paraffin temperature reduces. To understand the discharge process, the temperatures from all thirty T-type thermocouples in the PCM were recorded. The temperature measurements can help in identifying the dominant mode of heat transfer and location of the phase transition front at different locations in each zone of the LHTESS unit.

Fig. 11 present the measured temperatures for all thermocouples located in the thermal store during discharging with a $\mathrm{HTF}$ inlet temperature of $22{ }^{\circ} \mathrm{C}$ and a flow rate of $1.6 \mathrm{~L} / \mathrm{min}$. Due to the high temperature gradient between the HTF inlet temperature and the RT44HC in the LHTESS unit, the liquid PCM RT44HC at the bottom position in all six zones rapidly discharges the sensible thermal energy, stored in the liquid PCM above the phase transition temperature to the cold $\mathrm{HTF}$, with the RT44HC temperature reduced rapidly to $44{ }^{\circ} \mathrm{C}$. As can be seen in Fig. 11. during the phase transition, the temperature of RT44HC gradually reduces from $44{ }^{\circ} \mathrm{C}$ to $41^{\circ} \mathrm{C}$. After the latent portion of the PCMs thermal energy is discharged, a rapid decline in temperature is observed, which represents discharge of the sensible thermal energy from the solid PCM.

The length of time for which the measured temperatures stayed constant at $44^{\circ} \mathrm{C}$ is determined by the location of the probe and its proximity to the heat exchange surface. The HTF entered the heat exchanger in the store on the right-hand side and exited from the lefthand side illustrated in Fig. 11. Due to the HTF on the right-hand-side being colder than that on the left-hand side of the store the temperature difference between the HTF and RT44HC in zones (A), (B) and (C) is greater leading to high rates of heat transfer and rapid PCM solidification. The temperature of the HTF increases as heat is transferred from the RT44HC in zones (A), (B) and (C), reducing the temperature difference and thus rate of heat transfer to the HTF from the PCM in zones (D), (E) and (F), extending the time for phase change in these zones. Temperatures measured by thermocouples at level 5 (the upper-level) indicate 
solidification occurs quickly in this area. From the measured temperatures presented in Fig. 11 it is clear that natural convection does not play a significant role during the solidification process since the temperature profiles are not dependent on the height of the thermocouple within the store but on its horizontal position. 

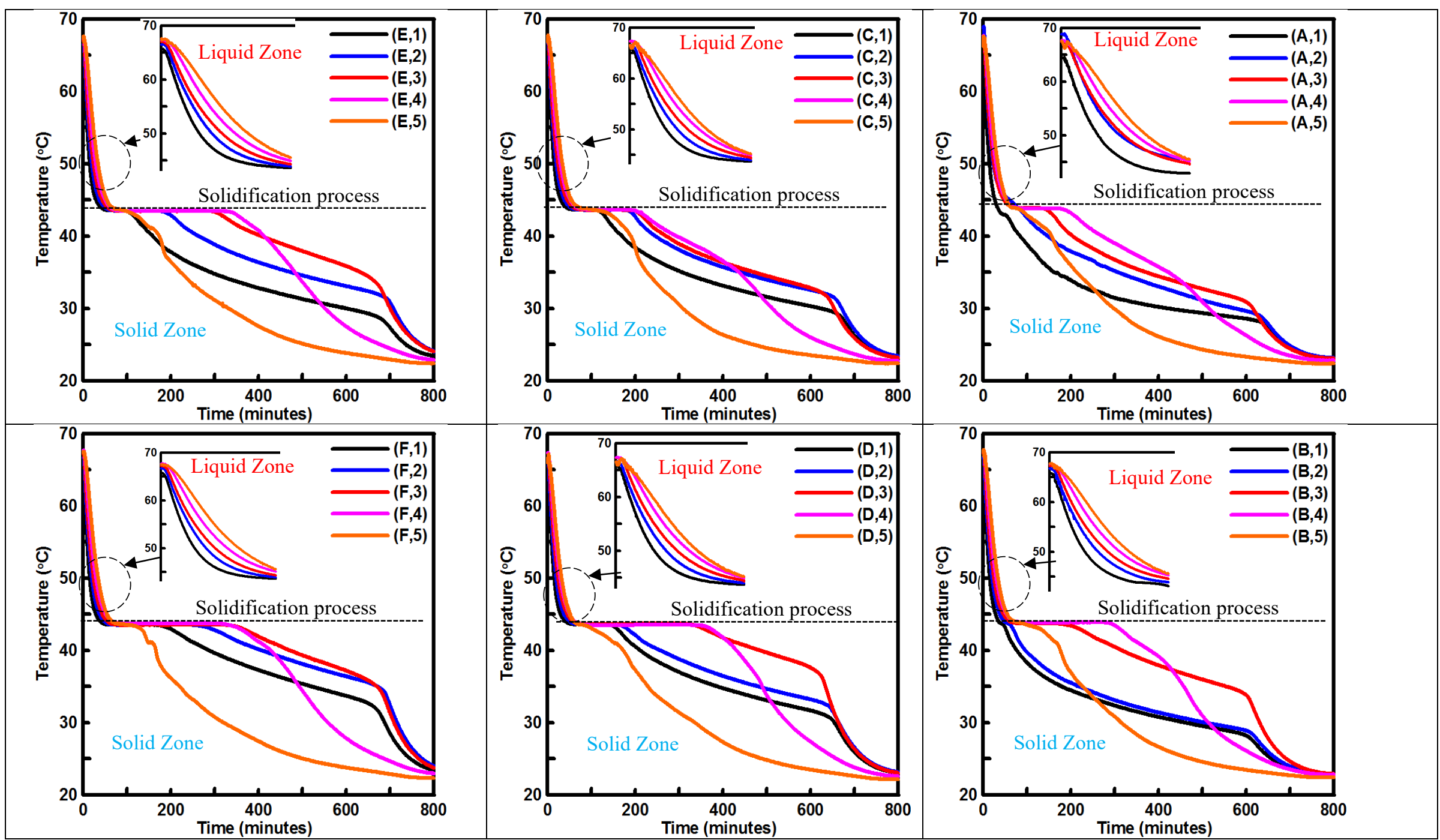

Fig. 11. Measured temperatures obtained during a discharging cycle at all six zones [(A), (B), (C), (D), (E) and (F)] and all five vertical positions within each zone. The HTF inlet temperature and volume flow rate were set at $22{ }^{\circ} \mathrm{C}$ and $1.6 \mathrm{~L} / \mathrm{min}$. 
Fig. 12 presents the power output, the cumulative energy discharged from the store and the HTF inlet and outlet temperatures as a function of time, for both discharge experiments. The power output decreases with time, due to the build-up of solid PCM on the heat exchanger surface with time.

From Fig. 12 for a volume flow rate $1.6 \mathrm{~L} / \mathrm{min}$, the maximum power output starts at $4.3 \mathrm{~kW}$ and drops to $1.0 \mathrm{~kW}$ after 100 minutes. The amount of heat discharged from the store was 5.5 kWh.

From Fig. 12 for a volume flow rate $3.0 \mathrm{~L} / \mathrm{min}$, the power output shows a similar trend to that observed for a volume flow rate of $1.6 \mathrm{~L} / \mathrm{min}$ with a peak power output of $10.5 \mathrm{~kW}$ with a total of $6.8 \mathrm{kWh}$ heat discharged from the store.

Although HTF flow rates were controlled the thermal stores were not initially at identical states of charge and the fluid inlet temperatures for discharge were not identical or constant being in the range of $20{ }^{\circ} \mathrm{C}$ to $25{ }^{\circ} \mathrm{C}$, the effects on store discharging cannot be attributed completely to changes in flow velocity. It is however known that an increase in HTF flow rate will increase the convective heat transfer coefficient within the heat exchanger, which will decrease the overall thermal resistance between the HTF and the PCM. An increase in temperature difference combined with an increase in the HTF flow rate will increase the heat transfer rate and thus discharge.

For a constant inlet temperature of the HTF, the heat transfer rate can be significantly influenced by varying the volume flow rate of the HTF with an effect on the discharge rate from the RT44HC in the LHTESS unit. An increase in the volume flow rate of HTF will reduce the discharge time due to the increased amount of heat removed by the HTF. The initial rapid decline in output temperature of the HTF seen in figure 12 is due to flushing hot heat transfer fluid out of the heat exchanger. To maintain a high outlet temperature of HTF for a longer period of time, a lower volume flow rate is required to allow sufficient heat to be transferred from the PCM. In practical applications, the volume flow rate will require regulation to meet application-specific demands of outlet temperature and duration of discharge time. 


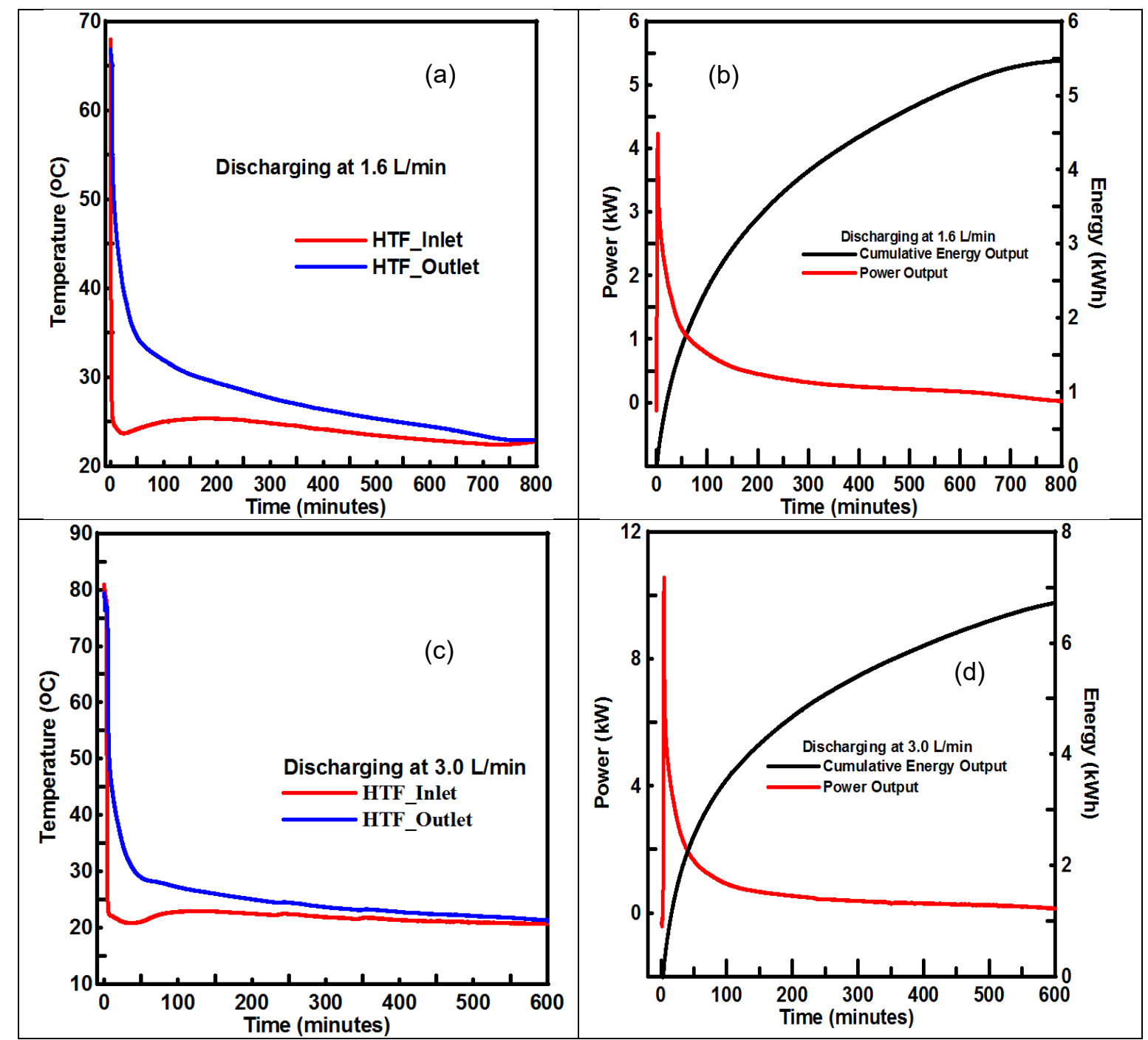

Fig.12. Power output and cumulative energy discharged during discharging for HTF inlet temperature of approximately $22^{\circ} \mathrm{C}$ and volume flow rates of $1.6 \mathrm{~L} / \mathrm{min}$ and $3.0 \mathrm{~L} / \mathrm{min}$.

\section{Conclusion}

This study provides a detailed examination of the phase change behaviour of paraffin wax RT44HC in a vertically oriented multi-pass tube heat exchanger aimed at DHW applications. The experimental measurements are sufficiently detailed to provide useful information and understanding to improve the design of vertically oriented multi-pass tube PCM heat exchangers. The series of experiments performed evaluated the overall thermal performance of the LHTESS for different HTF inlet temperatures and volume flow rates during both the charging and discharging process. The following conclusions were derived from the present study:

- Both melting, and solidification time decrease with increase HTF volume flow rate with the reduction in time being more pronounced for melting than solidification. 
- Initially, heat transfer in the PCM is dominated by conduction in the solid PCM during charging, subsequently as melting occurs and the liquid fraction increases, natural convection in the PCM becomes the dominant mode of heat transfer.

- During charging the PCM at the top of the store melts more rapidly compared to central and bottom locations due to natural convection in the PCM and higher-temperature liquid PCM rising due to buoyancy forces.

- At an inlet temperature of $70^{\circ} \mathrm{C}$, increasing the volume flow rate from $2.5 \mathrm{~L} / \mathrm{m}$ to 5.0 $\mathrm{L} / \mathrm{m}$ and $7.5 \mathrm{~L} / \mathrm{m}$ reduced the total melting time by $12 \%$ and $16.3 \%$, respectively.

- Increasing the HTF volume flow rate to $10.0 \mathrm{~L} / \mathrm{min}$, resulted in a minimal further reduction in melt time.

- For a constant volume flow rate $5.0 \mathrm{~L} / \mathrm{min}$, increasing the HTF inlet temperature from $60{ }^{\circ} \mathrm{C}$ to $70{ }^{\circ} \mathrm{C}$ and $80{ }^{\circ} \mathrm{C}$, reduced the total PCM melting time by $44.8 \%$ and $63.7 \%$, respectively.

- During discharging, for a volume flow rate of $1.6 \mathrm{~L} / \mathrm{min}$, the maximum power output starts at $4.3 \mathrm{~kW}$ and drops to $1.0 \mathrm{~kW}$ after100 minutes with $5.5 \mathrm{kWh}$ of heat delivered in total.

- At a volume flow rate of $3.0 \mathrm{~L} / \mathrm{min}$, the trend in power output is similar to that with a volume flow rate of $1.6 \mathrm{~L} / \mathrm{min}$ with a peak output of $10.5 \mathrm{~kW}$ and a total of $6.8 \mathrm{kWh}$ of heat delivered.

- Depending on application requirements, the thermal storage capacity and power delivery can be increased by employing several LHTSS units in parallel. By using a modular approach LHTSS can provide a versatile element of largescale systems in which there is a temporal mismatch between supply and demand.

\section{Acknowledgement}

The authors are grateful to the Engineering and Physical Sciences Research Council (EPSRC) for funding this work through Grant reference EP/N021304/1(Small Smart Sustainable Systems for future Domestic Hot Water (4S-DHW) and EP/K011847/1 Interdisciplinary Centre for Storage, Transformation and Upgrading of Thermal Energy (i-STUTE).

\section{References}

[1] Palmer J, Cooper I, Lipson M, Lomas K, Firth S, Allinson D. United Kingdom housing energy fact file. Cambridge Econom. 
[2] UK Climate Change Act: Understanding the costs and benefits. https://www.carbonbrief.org/uk-climate-change-act-costs-benefits (accessed July 17, 2019).

[3] Climate Change Act 2008. https://www.legislation.gov.uk/ukpga/2008/27/contents (accessed October 3, 2018).

[4] Abu-Bakar SH, Muhammad-Sukki F, Ramirez-Iniguez R, Mallick TK, McLennan C, Munir AB, et al. Is Renewable Heat Incentive the future? Renew Sustain Energy Rev 2013;26:365-78. doi:10.1016/J.RSER.2013.05.044.

[5] Kalogirou SA, Kalogirou SA. Solar Water Heating Systems. Sol Energy Eng 2009:251314. doi:10.1016/B978-0-12-374501-9.00005-4.

[6] Renewables \&amp; Renewable Energy | Energy Saving Trust n.d. http://www.energysavingtrust.org.uk/renewable-energy (accessed December 3, 2018).

[7] Monde AD, Shrivastava A, Chakraborty PR. Solar Thermal Energy Storage, Springer, Singapore; 2018, p. 131-62. doi:10.1007/978-981-10-7206-2_8.

[8] Prieto C, Cooper P, Fernández AI, Cabeza LF. Review of technology: Thermochemical energy storage for concentrated solar power plants. Renew Sustain Energy Rev 2016;60:909-29. doi:10.1016/j.rser.2015.12.364.

[9] Dincer I. On thermal energy storage systems and applications in buildings. Energy Build 2002;34:377-88. doi:10.1016/S0378-7788(01)00126-8.

[10] Agyenim F, Hewitt N, Eames P, Smyth M. A review of materials, heat transfer and phase change problem formulation for latent heat thermal energy storage systems (LHTESS). Renew Sustain Energy Rev 2010;14:615-28. doi:10.1016/j.rser.2009.10.015.

[11] Parry AJ, Eames PC, Agyenim F. Modeling of Thermal Energy Storage Shell-and-Tube Heat Exchanger. Heat Transf Eng 2014;35:1-14. doi:10.1080/01457632.2013.810057.

[12] Agyenim F, Eames P, Smyth M. A comparison of heat transfer enhancement in a medium temperature thermal energy storage heat exchanger using fins. Sol Energy 2009;83:1509-20. doi:10.1016/j.solener.2009.04.007.

[13] da Cunha JP, Eames P. Compact latent heat storage decarbonisation potential for domestic hot water and space heating applications in the UK. Appl Therm Eng 2018;134:396-406. doi:10.1016/J.APPLTHERMALENG.2018.01.120.

[14] Fadl M, Eames PC. Numerical investigation of the influence of mushy zone parameter Amush on heat transfer characteristics in vertically and horizontally oriented thermal energy storage systems. Appl Therm Eng 2019;151:90-9. doi:https://doi.org/10.1016/j.applthermaleng.2019.01.102.

[15] Pereira da Cunha J, Eames P. Thermal energy storage for low and medium temperature applications using phase change materials - A review. Appl Energy 2016;177:227-38. doi:10.1016/j.apenergy.2016.05.097.

[16] Fadl M, Eames PC. A comparative study of the effect of varying wall heat flux on melting characteristics of phase change material RT44HC in rectangular test cells. Int J 
Heat

Mass

Transf

2019;141:731-47.

doi:10.1016/J.IJHEATMASSTRANSFER.2019.07.038.

[17] Farid MM, Khudhair AM, Razack SAK, Al-Hallaj S. A review on phase change energy storage: materials and applications. Energy Convers Manag 2004;45:1597-615. doi:10.1016/J.ENCONMAN.2003.09.015.

[18] Fadl M, Eames PC. An experimental investigations of the melting of RT44HC inside a horizontal rectangular test cell subject to uniform wall heat flux. Int J Heat Mass Transf 2019;140:731-42. doi:10.1016/j.ijheatmasstransfer.2019.06.047.

[19] Fadl M, Eames P. A Numerical Investigation into the Heat Transfer and Melting Process of Lauric Acid in a Rectangular Enclosure with Three Values of Wall Heat Flux. Energy Procedia 2019;158:4502-9. doi:10.1016/J.EGYPRO.2019.01.761.

[20] Fadl M, Eames P. A comparative study of the effect of wall heat flux on melting and heat transfer characteristics in phase change material thermal energy stores arranged vertically and horizontally. 9th Ed Int SOLARIS Conf, Chengdu, China: IOP Conference Series: Materials Science and Engineering (MSE); 2018. doi:10.1088/issn.1757-899X.

[21] Fadl MS, Eames PC. An experimental investigation of the heat transfer and energy storage characteristics of a latent heat thermal energy storage system with a verticallyoriented multi-pass tube heat exchanger for domestic hot water applications. Eurotherm Semin \#112 Adv Therm Energy Storage 2019.

[22] Regin AF, Solanki SCC, Saini JSS. Heat transfer characteristics of thermal energy storage system using PCM capsules: A review. Renew Sustain Energy Rev 2008;12:2438-58. doi:10.1016/j.rser.2007.06.009.

[23] Nazir H, Batool M, Bolivar Osorio FJ, Isaza-Ruiz M, Xu X, Vignarooban K, et al. Recent developments in phase change materials for energy storage applications: A review. Int J Heat Mass Transf 2019;129:491-523. doi:10.1016/J.IJHEATMASSTRANSFER.2018.09.126.

[24] Xu B, Li P, Chan C. Application of phase change materials for thermal energy storage in concentrated solar thermal power plants: A review to recent developments. Appl Energy 2015;160:286-307. doi:10.1016/j.apenergy.2015.09.016.

[25] Saydam V, Parsazadeh M, Radeef M, Duan X. Design and experimental analysis of a helical coil phase change heat exchanger for thermal energy storage. J Energy Storage 2019;21:9-17. doi:10.1016/J.EST.2018.11.006.

[26] Tay NHS, Belusko M, Bruno F. An effectiveness-NTU technique for characterising tube-in-tank phase change thermal energy storage systems. Appl Energy 2012;91:30919. doi:10.1016/j.apenergy.2011.09.039.

[27] Meng ZN, Zhang P. Experimental and numerical investigation of a tube-in-tank latent thermal energy storage unit using composite PCM 2017. doi:10.1016/j.apenergy.2016.12.163.

[28] Jesumathy SPP, Udayakumar M, Suresh S, Jegadheeswaran S. An experimental study on heat transfer characteristics of paraffin wax in horizontal double pipe heat latent heat 
storage unit. J Taiwan Inst Chem Eng 2014;45:1298-306. doi:10.1016/j.jtice.2014.03.007.

[29] Seddegh S, Joybari MM, Wang X, Haghighat F. Experimental and numerical characterization of natural convection in a vertical shell-and-tube latent thermal energy storage system 2017. doi:10.1016/j.scs.2017.07.024.

[30] Rubitherm GmbH. /www.rubitherm.eu/ (accessed February 21, 2018).

[31] Liu C, Groulx D. Experimental study of the phase change heat transfer inside a horizontal cylindrical latent heat energy storage system. Int J Therm Sci 2014;82:10010. doi:10.1016/j.ijthermalsci.2014.03.014.

[32] Hot Water Cylinders Kingspan https://www.kingspan.com (accessed December 17, 2018).

[33] Huber Unistat 510w Dynamic temperature control system circulation www.huberonline.com (accessed December 14, 2018).

[34] Pumps with peripheral impeller www.pedrollo.com (accessed December 14, 2018).

[35] FT-110 Series TurboFlow https://www.gemssensors.co.uk (accessed December 14, 2018).

[36] dataTaker- DT85 Data Logger n.d. http://www.datataker.com/DT85.php (accessed February 2, 2018).

[37] TA Instruments. Differential Scanning Calorimeters 2015. http://www.tainstruments.com/products/thermal-analysis/differential-scanningcalorimeters/ (accessed February 21, 2018).

[38] TA INSTRUMENTS. Chem Eng News 2010;84:ibc. doi:10.1021/cen-v084n042.ibc.

[39] Ling Z, Chen J, Xu T, Fang X, Gao X, Zhang Z. Thermal conductivity of an organic phase change material/expanded graphite composite across the phase change temperature range and a novel thermal conductivity model. Energy Convers Manag 2015;102:202-8. doi:10.1016/J.ENCONMAN.2014.11.040.

[40] Moffat RJ. Describing the uncertainties in experimental results. Exp Therm Fluid Sci 1988;1:3-17. doi:10.1016/0894-1777(88)90043-X.

[41] Khan Z, Khan ZA. Experimental investigations of charging/melting cycles of paraffin in a novel shell and tube with longitudinal fins based heat storage design solution for domestic and industrial applications. Appl Energy 2017;206:1158-68. doi:10.1016/J.APENERGY.2017.10.043.

\begin{tabular}{|l|l|}
\hline \multicolumn{2}{|l|}{ NOMENCLATURE } \\
\hline $\mathrm{C}_{\mathrm{p}}$ & Specific heat at constant pressure $\left(\mathrm{J} / \mathrm{kg}^{\circ} \mathrm{C}\right)$ \\
\hline $\mathrm{m}$ & Mass $(\mathrm{kg})$ \\
\hline $\mathrm{m}^{\circ}$ & Mass flow rate $(\mathrm{kg} / \mathrm{s})$ \\
\hline $\mathrm{Q}$ & Energy $[\mathrm{J}]$ \\
\hline
\end{tabular}




\begin{tabular}{|l|l|}
\hline$\dot{\mathrm{Q}}$ & Power $[\mathrm{W}]$ \\
\hline $\mathrm{K}$ & Thermal conductivity $\left(\mathrm{W} / \mathrm{m}^{\circ} \mathrm{C}\right)$ \\
\hline $\mathrm{PCM}$ & Phase change material \\
\hline $\mathrm{T}$ & Temperature $\left({ }^{\circ} \mathrm{C}\right)$ \\
\hline $\mathrm{t}$ & Time $(\mathrm{s})$ \\
\hline $\mathrm{w}$ & Estimated uncertainty in the final results \\
\hline $\mathrm{y}$ & Independent measured parameter \\
\hline Greek symbols & \\
\hline$\beta$ & Volumetric expansion coefficient \\
\hline$\Delta \mathrm{h}_{\mathrm{m}}$ & Latent heat $(\mathrm{J} / \mathrm{kg})$ \\
\hline$\Delta \mathrm{T}$ & Temperature difference $\left[{ }^{\circ} \mathrm{C}\right]$ \\
\hline$\mu$ & Dynamic viscosity \\
\hline Subscripts & \\
\hline Cumulative & Cumulative energy input \\
\hline $\mathrm{f}$ & Final \\
\hline $\mathrm{HTF}$ & Heat transfer fluid \\
\hline PCM & Phase change material \\
\hline $\mathrm{s}$ & Solid \\
\hline stored & Energy stored \\
\hline TES & Thermal energy storage \\
\hline 1 & Liquid \\
\hline LHTESS & Latent heat thermal energy storage system \\
\hline in & Initial \\
\hline Italic & \multicolumn{2}{|l|}{} \\
\hline liq & Liquid \\
\hline$s$ & Solid \\
\hline Abbreviations & Climate change agreement \\
\hline CCA & Domestic hot water \\
\hline DHW & Latent heat energy storage systems \\
\hline LHTESS. & Number of Transfer Units \\
\hline NTU & Solar water heating system \\
\hline SWHS &
\end{tabular}

